\title{
Molecular detection and characterization of Babesia bovis, Babesia bigemina, Theileria species and Anaplasma marginale isolated from cattle in Kenya
}

\author{
Paul Franck Adjou Moumouni 1,3, Gabriel Oluga Aboge ${ }^{1,2}$, Mohamad Alaa Terkawi ${ }^{1}$, Tatsunori Masatani ${ }^{1}$, \\ Shinuo Cao ${ }^{1}$, Ketsarin Kamyingkird', Charoonluk Jirapattharasate ${ }^{1}$, Mo Zhou', Guanbo Wang ${ }^{1}$, Mingming Liu', \\ Aiko Iguchi ${ }^{1}$, Patrick Vudriko ${ }^{1}$, Adrian Patalinghug Ybanez ${ }^{4}$, Hisashi Inokuma ${ }^{3,4}$, Rika Shirafuji-Umemiya ${ }^{1}$, \\ Hiroshi Suzuki ${ }^{1,3}$ and Xuenan Xuan ${ }^{1 *}$
}

\begin{abstract}
Background: Infections with Babesia bovis, Babesia bigemina, Theileria species and Anaplasma marginale are endemic in Kenya yet there is a lack of adequate information on their genotypes. This study established the genetic diversities of the above tick-borne hemoparasites infecting cattle in Kenya.

Methods: Nested PCR and sequencing were used to determine the prevalence and genetic diversity of the above parasites in 192 cattle blood samples collected from Ngong and Machakos farms. B. bovis spherical body protein 4, B. bigemina rhoptry-associated protein 1a, A. marginale major surface protein 5, Theileria spp. $18 \mathrm{~S}$ rRNA, T. parva p104 and T. orientalis major piroplasm surface protein were used as the marker genes.
\end{abstract}

Results: B. bovis, B. bigemina, T. parva, T. velifera, T. taurotragi, T. mutans and A. marginale were prevalent in both farms, whereas T. ovis, Theileria sp. (buffalo) and T. orientalis were found only in Ngong farm. Co-infections were observed in more than $50 \%$ of positive samples in both farms. Babesia parasites and A. marginale sequences were highly conserved while T. parva and T. orientalis were polymorphic. Cattle-derived T. parva was detected in Machakos farm. However, cattle and buffalo-derived Theileria were detected in Ngong farm suggesting interactions between cattle and wild buffaloes. Generally, the pathogens detected in Kenya were genetically related to the other African isolates but different from the isolates in other continents.

Conclusions: The current findings reaffirm the endemicity and co-infection of cattle with tick-borne hemoparasites, and the role of wildlife in pathogens transmission and population genetics in Kenya.

Keywords: Epidemiology, PCR, Babesia, Theileria, Anaplasma, Cattle, Kenya

\section{Background}

Babesiosis, theileriosis and anaplasmosis are important tick-borne diseases of cattle worldwide including Kenya. Babesiosis and theileriosis are caused by the protozoan parasites, Babesia and Theileria respectively while anaplasmosis is caused by rickettsial organism known as Anaplasma. In Africa including Kenya, bovine babesiosis

\footnotetext{
* Correspondence: gen@obihiro.ac.jp

${ }^{1}$ National Research Center for Protozoan Diseases, Obihiro University of Agriculture and Veterinary Medicine, Obihiro, Hokkaido 080-8555, Japan Full list of author information is available at the end of the article
}

is caused by Babesia bovis and B. bigemina and the disease is transmitted by Rhipicephalus ticks [1]. Though, $B$. bigemina is more widespread, $B$. bovis infection is the most critical and fatal because of its neurological symptoms [2].

Bovine theileriosis is another tick-borne disease found in many African countries. Tropical theileriosis and East Coast fever (ECF) are the most severe forms of the disease. Tropical theileriosis, caused by T. annulata and transmitted by Hyalomma ticks is distributed in Northern Africa. ECF is probably the most important tick-borne disease in 
Eastern, Central and Southern Africa. The disease is caused by Theileria parva and transmitted mainly by Rhipicephalus appendiculatus. T. parva natural host is the African Cape buffalo (Syncerus caffer), which serves as source of infection for cattle. Some variants of the parasite are transmitted solely from buffalo to cattle whereas others can spread from cattle to cattle. The other Theileria species reported in Africa are T. mutans, T. taurotragi, T. sergenti/ buffeli/orientalis (referred to as $T$. orientalis complex) and T. velifera. These species are considered to be either less pathogenic or not pathogenic at all, and only cause benign, moderate to asymptomatic theileriosis [3]. For bovine anaplasmosis, Anaplasma marginale is one of the causative agents and this pathogen is transmitted biologically, by approximately twenty tick species, and mechanically by biting flies and blood-contaminated fomite [4].

B. bovis, B. bigemina, T. parva, T. annulata and $A$. marginale cause mortalities and morbidities leading to losses in production of milk, meat, and other livestock by-products. Consequently, they cause severe economic losses to livestock farmers involved in dairy and beef production in tropical and sub-tropical regions [5]. In Kenya, theileriosis, anaplasmosis and babesiosis are ranked among the most common causes of economic losses in dairy and beef industry [6-8]. The diagnosis of these diseases in Kenyan cattle have relied mostly on clinical signs [6], microscopic examination of blood smears [6, 9-12] and antibody detection [12-14]. A few studies employing molecular methods (polymerase chain reaction (PCR), reverse line blot hybridization (RLB), real time $\mathrm{PCR}$ ) and genome sequencing have been exploited in Kenya [15-18]. However, these studies have been limited to a few tick-borne diseases with most of the studies lacking adequate information on their genotypes or even knowledge on their molecular epidemiology, which is critical for the control and prevention of these diseases.

Therefore, this study was done with the main objective of determining and understanding the genetic diversities and molecular epidemiology of some species of Babesia, Theileria and Anaplasma pathogens infecting cattle in Kenya. In particular, blood samples of cattle raised in farms located in Machakos and Ngong districts of Kenya were screened for specific target genes of B. bovis, B. bigemina, Theileria spp. and $A$. marginale. The sequences generated from these target genes were used to confirm the identity of the pathogens and establish phylogenies to aid in the understanding of their molecular epidemiology in Kenya in relation to other regions of the world.

\section{Methods}

Study areas and blood samples collection

Two separate dairy cattle farms were investigated in Kenya with one farm located in Ngong district of Kajiado
County and the other farm is located in Machakos district of Machakos County. The farm in Ngong district $\left(1^{\circ} 22^{\prime} \mathrm{S}\right.$, $\left.36^{\circ} 38^{\prime} \mathrm{E}\right)$ lies $22 \mathrm{~km}$ Southwest of Nairobi whereas the other one in Machakos district $\left(1^{\circ} 14^{\prime} \mathrm{S}, 37^{\circ} 23^{\prime} \mathrm{E}\right)$ lies $63 \mathrm{~km}$ Southeast of Nairobi. The average annual temperatures and rainfalls are $16.7{ }^{\circ} \mathrm{C}, 865 \mathrm{~mm}$ and $19.0{ }^{\circ} \mathrm{C}$, $830 \mathrm{~mm}$ for Ngong and Machakos, respectively [19]. Cattle in both farms are kept under a semi-extensive system, characterized by free grazing on pastures. The cattle were kept under semi-enclosed system at night and allowed to graze on pastures where the animals mixed with Masaai cattle grazing in the same area. The grazing together with Masaai cattle was particularly seen in case of cattle kept in Ngong farm.

A total of 154 and 38 blood samples were collected in EDTA-vacutainer tubes from cattle in Ngong and Machakos farms, respectively during a cross-sectional survey done in August 2011. The samples were collected from randomly selected male and female crossbred cattle including adults and yearlings; all of which were apparently healthy. The samples were then transported on ice to the Central Veterinary Laboratory in Nairobi, Kenya and stored at $-20{ }^{\circ} \mathrm{C}$ prior to DNA extraction.

\section{Ethical statement}

The managers of surveyed farms were informed about the study and gave their approval for the sampling of cattle. All the procedures were carried out according to ethical guidelines for the use of animal samples permitted by Obihiro University of Agriculture and Veterinary Medicine (Permit for animal experiment: 26-73, 26-72; DNA experiment: 1219-3; Pathogen: 201210-5; 201206-5).

\section{Extraction of hemoparasites DNA}

The genomic DNA was extracted at the Central Veterinary Laboratory in Nairobi, Kenya using a commercial DNA extraction kit according to the manufacturer's instructions (QIAamp DNA Blood Mini-Kit, Germany). The extracted DNA samples were transported to the National Research Center for Protozoan diseases in Obihiro, Japan where they were stored at $-30{ }^{\circ} \mathrm{C}$ pending further genetic analysis.

\section{Hemoparasites DNAs-detection by $\mathrm{nPCR}$}

Specific primers targeting $B$. bovis spherical body protein-4 (SBP-4), B. bigemina rhoptry-associated protein-1a (RAP-1a), Theileria spp. 18S rRNA and A. marginale major surface protein 5 (Msp5) genes were used to amplify the respective genes by using previously described nPCRs [20-22]. Initial PCR amplifications were done in a $10 \mu$ l-reaction mixture having $1 \mu \mathrm{l}$ of DNA template, $1 \mu \mathrm{l}$ $(10 \mu \mathrm{M})$ of each primers, $1 \mu$ lof $10 \mathrm{x}$ Ex buffer, $1 \mu \mathrm{l}$ of dNTP (200 $\mu \mathrm{M}$ each), $0.1 \mu \mathrm{l}$ of Ex Taq polymerase (Takara, Japan) and $4.9 \mu \mathrm{l}$ of double distilled water. A nested PCR was done using $1 \mu \mathrm{l}$ of DNA template 
obtained from the first PCR amplification. Primers and thermocycling conditions were as described previously (Table 1) except for $A$. marginale in which a touch down PCR was done. The following samples were used as positive controls; DNAs of B. bigemina (Argentina strain), B. bovis (Texas strain), T. parva (Muguga G6,ILRI), T. annulata (Ankara C9,Edinburgh University), cattle DNA sample positive for T. orientalis and A.marginale-Msp5 plasmid [22]. Double distilled water was used as a negative control. The nPCR products were electrophoresed, stained with ethidium bromide and then visualized under UV transilluminater.

To detect co-infection with T. parva and T. orientalis complex, samples positive for Theileria spp. $18 \mathrm{~S}$ rRNA were further amplified by nPCR using primers targeting T. parva p104 (p104) gene [23] for $T$. parva and those targeting $T$. orientalis major piroplasm surface protein (MPSP) gene [24] for $T$. orientalis.

\section{Sequencing of the hemoparasites DNAs}

All Theileria spp. positive samples and randomly selected positive samples of B. bovis, B. bigemina, T. parva, T. orientalis complex and $A$. marginale (three samples for each parasite per farm) were used as templates for genetic characterization of the hemoparasites. Nested PCR amplicons of Theileria spp. $18 \mathrm{~S}$ rRNA, B. bovis SBP-4 and $T$. parva p104; PCRs amplicons of $A$. marginale Msp5 and T.orientalis MPSP; and the products of $B$. bigemina RAP1a-semi-nPCR (Table 1) were purified by using QIAquick Gel Extraction Kit (QIAGEN GmbH, Germany). The Theileria spp. 18S rRNA amplicons were sequenced with the nPCR primers. DNA sequences with heterozygous base-calling were analyzed using Mixed Sequence Reader web-based program [25] and identified as two distinct sequences. The other purified DNA templates were first sequenced with the amplification primers to identify heterozygous base-calling positions and then cloned in pGEM-T Easy Vector (Promega, USA). Initially, two

Table 1 Sequences of primers set used for detection of hemoparasites DNAs

\begin{tabular}{|c|c|c|c|c|}
\hline $\begin{array}{l}\text { Pathogen } \\
\text { Target gene }\end{array}$ & Assays & Oligonucleotide sequences $\left(5^{\prime}>3^{\prime}\right)$ & $\begin{array}{l}\text { Product } \\
\text { size (bp) }\end{array}$ & Reference \\
\hline \multirow[t]{4}{*}{ B. bovis SBP-4 } & PCR & AGTTGTTGGAGGAGGCTAAT & 907 & {$[21]$} \\
\hline & & TCCTTCTCGGCGTCCTITIC & & \\
\hline & $\mathrm{nPCR}$ & GAAATCCCTGTTCCAGAG & 503 & \\
\hline & & TCGTTGATAACACTGCAA & & \\
\hline \multirow[t]{6}{*}{ B. bigemina RAP-1a } & PCR & GAGTCTGCCAAATCCTTAC & 879 & \\
\hline & & TCCTCTACAGCTGCTTCG & & \\
\hline & $\mathrm{nPCR}$ & AGCTTGCTTTCACAACTCGCC & 412 & \\
\hline & & TTGGTGCTTTGACCGACGACAT & & \\
\hline & semi nPCR & GAGTCTGCCAAATCCTTAC & 690 & \\
\hline & & TTGGTGCTTTGACCGACGACAT & & \\
\hline \multirow[t]{4}{*}{ Theileria spp. $18 \mathrm{~S}$ rRNA } & PCR & GAAACGGCTACCACATCT & 778 & {$[20]$} \\
\hline & & AGTTTCCCCGTGTTGAGT & & \\
\hline & $\mathrm{nPCR}$ & TTAAACCTCTTCCAGAGT & 581 & \\
\hline & & TCAGCCTTGCGACCATAC & & \\
\hline \multirow[t]{4}{*}{ T. parva p 104} & PCR & ATTTAAGGAACCTGACGTGACTGC & 496 & {$[23]$} \\
\hline & & TAAGATGCCGACTATTAATGACACC & & \\
\hline & $\mathrm{nPCR}$ & GGCCAAGGTCTCCTTCAGATTACG & 277 & \\
\hline & & TGGGTGTGTTTCCTCGTCATCTGC & & \\
\hline \multirow[t]{2}{*}{ T. orientalis MPSP } & PCR & CTITGCCTAGGATACTTCCT & 776 & {$[24]$} \\
\hline & & ACGGCAAGTGGTGAGAACT & & \\
\hline \multirow[t]{4}{*}{ A. marginale Msp5 } & PCR & GTGTTCCTGGGGTACTCCTATGTGAACAAG & 547 & {$[22]$} \\
\hline & & AAGCATGTGACCGCTGACAAACTTAAACAG & & \\
\hline & $\mathrm{nPCR}$ & AAGCACATGTTGGTAATATTCGGCTTCTCA & 195 & \\
\hline & & AATTCTCGCATCAAAAGACTTGTGGTACTC & & \\
\hline
\end{tabular}

Note: The primers sets forSBP-4, 18S rRNA, p104 and MPSP genes were used for detection of corresponding pathogens and the products of the last amplification served as template for genetic characterisation. With regard to BbigRAP-1a and Msp5, PCR and nPCR primers were used in pathogen detection, however for genetic characterization, amplicons from a semi-nPCR (BbigRAP-1) and from the first PCR (Msp5) were used 
positive clones per template were randomly selected and sequenced with pGEM-T Easy Vector-primers (pUC/ M13). When the sequences of the clones did not include all the genotypes identified during direct sequencing, other two clones from the same template were sequenced. All sequencing analysis assays were performed using the Dye Terminator Cycle Sequencing Kit (Applied Biosystems, USA) and an ABI PRISM 3100 genetic analyzer (Applied Biosystems, USA).

\section{Blast analysis, sequence alignment and phylogenetic analysis}

The sequenced DNAs were analyzed by BLASTn tool of NCBI GenBank database. The correct species identity was established by comparing the query sequences with those available in the GenBank database. Species confirmation was done when the closest BLASTn match has a $98 \%-100 \%$ identity to the homologues found in the GenBank. DNA sequences identities were also computed using the pairwise alignment by EMBOSS NEEDLE software [26]. Multiple sequence alignments were performed using MUSCLE and GUIDANCE algorithms [27]. Phylogenetic analyses were inferred by the maximum likelihood method using MEGA version 6 software [28].

\section{Statistical analysis}

Proportions of DNA samples positive for respective hemoparasites per farm were computed and a comparison of pathogen prevalence was done using the chi-square test employing the EPI INFO ${ }^{\mathrm{TM}}$ software (CDC, USA, version 7.1.1) and VassarStats [29]. Statistically significant differences were determined at $P<0.05$.

\section{Nucleotide sequences accession numbers}

The nucleotide sequences of all the genes sequenced are available in the GenBank of the NCBI database under the accession numbers outlined in Table 2 .

\section{Results}

\section{Detection of hemoparasites in cattle by $\mathrm{nPCR}$}

A total of 192 blood samples (154 in Ngong and 38 in Machakos) were analyzed by nPCR to be able to detect infection of cattle with B. bovis, B. bigemina, Theileria spp. and $A$. marginale. Of these samples, at least one of the hemoparasites named above was detected in 135 (70 \%) samples. In Ngong farm, 110 (71 \%) samples had hemoparasites DNAs with B. bigemina (65 samples- $42.2 \%$ ) being more prevalent than $B$. bovis (19 samples-12.3\%). On the other hand, Theileria spp. and A. marginale DNAs were detected in 52 (33.8 \%) and 50 (32.5\%) blood samples, respectively. Overall, 25 (66\%) samples were positive for at least one hemoparasite in Machakos. In particular, 9 (23.7\%) samples were positive for B. bovis while B. bigemina was detected in $5(13.2 \%)$ samples. Theileria spp.
Table 2 Accession numbers of DNA sequences deposited in GenBank for the hemoparasites detected in this study

\begin{tabular}{|c|c|c|c|}
\hline $\begin{array}{l}\text { Parasite } \\
\text { isolate } \\
\end{array}$ & $\begin{array}{l}\text { Target } \\
\text { genes }\end{array}$ & $\begin{array}{l}\text { Accession } \\
\text { numbers }\end{array}$ & $\begin{array}{l}\text { Sequence length } \\
\text { (bp) }\end{array}$ \\
\hline \multirow[t]{3}{*}{ B. bovis } & \multirow[t]{3}{*}{ SBP-4 } & KP347555 & 521 \\
\hline & & KP347556 & 521 \\
\hline & & KP347557 & 521 \\
\hline \multirow[t]{3}{*}{ B. bigemina } & \multirow[t]{3}{*}{ RAP-1a } & KP347558 & 690 \\
\hline & & KР347559 & 690 \\
\hline & & KP893330 & 690 \\
\hline \multirow[t]{2}{*}{ A. marginale } & \multirow[t]{2}{*}{ Msp5 } & KP347553 & 576 \\
\hline & & KР347554 & 576 \\
\hline \multirow[t]{9}{*}{ Theileria spp. } & \multirow[t]{9}{*}{$18 \mathrm{~S}$ rRNA } & KP347567 & 486 \\
\hline & & KP347568 & 493 \\
\hline & & KP347569 & 497 \\
\hline & & KP347570 & 515 \\
\hline & & KP347571 & 512 \\
\hline & & KP347572 & 512 \\
\hline & & KP347573 & 488 \\
\hline & & KP347574 & 514 \\
\hline & & KP347575 & 469 \\
\hline \multirow[t]{3}{*}{ T. parva } & \multirow[t]{3}{*}{ p104 } & KР347564 & 278 \\
\hline & & KP347565 & 278 \\
\hline & & KP347566 & 278 \\
\hline \multirow[t]{4}{*}{ T. orientalis } & \multirow[t]{4}{*}{ MPSP } & KP347560 & 776 \\
\hline & & KP347561 & 776 \\
\hline & & KP347562 & 776 \\
\hline & & KP347563 & 776 \\
\hline
\end{tabular}

and A. marginale were detected in 15 (39.5\%) and 6 $(15.8 \%)$ samples, respectively. There was statistically significant difference in prevalences observed in the two farms $(P<0.05)$ for $B$. bigemina and $A$. marginale. Individual results for each parasite are shown in an additional file [see Additional file 1].

\section{Identification of Theileria species}

Genetic analysis of the sequenced Theilera spp.-18S rRNAs revealed homologues that belonged to seven distinct Theileria species including $T$. parva, T. taurotragi, $T$. mutans, T. velifera, T.orientalis complex, T. ovis and Theileria sp. (buffalo) (Table 3). In particular, T. parva, T. taurotragi, $T$. mutans and $T$. velifera were detected in samples from cattle in both farms while $T$. orientalis complex, $T$. ovis and Theileria sp. (buffalo) were detected in Ngong farm-cattle only. Co-infections with T. parva and T. taurotragi, T.mutans and T. taurotragi were observed in some blood samples from Ngong farm-cattle. Other samples with T. parva and T. velifera co-infections were seen in the same farm. In contrast, co-infections with $T$. taurotragi and $T$. 
Table 3 Identification of Theileria species by BLASTn analysis of the $18 \mathrm{~S}$ rRNA sequences of the isolates from cattle in Kenya

\begin{tabular}{llll}
\hline $\begin{array}{l}\text { Accession } \\
\text { number }\end{array}$ & $\begin{array}{l}\text { Highest Blastn } \\
\text { match }\end{array}$ & $\begin{array}{l}\text { Accession number } \\
\text { of match }\end{array}$ & identity \\
\hline KP347567 & T. mutans & AF078815 & 99 \\
KP347568 & T. orientalis & AB520955 & 100 \\
& T. sergenti & JQ723015 & \\
& T. buffeli & DQ287959 & \\
KP347569 & Theileria sp. JW-2014 & KJ020546 & \\
KP347570 & T. ovis & KM924444 & 100 \\
KP347571 & T. taurotragi & LQ684067 & 100 \\
KP347572 & T. taurotragi & L19082 & 99 \\
KP347573 & T. taurotragi & L19082 & 100 \\
KP347574 & T. velifera & JN572705 & 100 \\
KP347575 & Theileria sp.(buffalo) & HQ895982 & 100 \\
\hline & & &
\end{tabular}

velifera were detected in cattle from Machakos farm only. All the samples that were positive for T. parva and T. orientalis complex $18 \mathrm{~S}$ rRNAs were also positive for $T$. parva p104 and T. orientalis MPSP genes, respectively. Thirty five samples from Ngong farm and 11 samples from Machakos farm that were negative for $T$. parva $18 \mathrm{~S}$ rRNA were found to be positive for T. parva p104 DNA. T. parva was the most prevalent with the parasite DNA being detected in 46 $(29.9 \%)$ and $12(31.6 \%)$ samples from cattle in Ngong and Machakos farms, respectively. Infections with $T$. velifera, $T$. taurotragi and T. mutans were also observed though less frequently. Few cases of T.orientalis complex, T. ovis and Theileria sp. (buffalo) infections were detected. Detailed results of Theileria species identification are shown in an additional file [see Additional file 2].

\section{Mixed infections with Babesia, Theileria and Anaplasma}

More than half of the positive samples were infected with at least two hemoparasites, which generally belonged to different genus. Twenty nine different types of mixed infections were seen in Ngong farm with some cattle having up to five pathogens coinfecting the same cattle (Table 4). In Machakos farm, 11 different types of mixed infections were seen with up to three pathogens simultaneously being detected in some samples (Table 5). Single infections with $B$. bovis, T. velifera and $A$. marginale were observed in both farms, while single infections with $B$. bigemina and T. parva were seen in Ngong farm only. In most cases, mixed infections rather than single infection were detected for all hemoparasites in both farms except for B. bovis for which most of positive samples in Machakos farm were single infections (Table 5).
Table 4 Tick-borne hemoparasites detected in cattle $(n=154)$ from Ngong-farm in Kenya

\begin{tabular}{|c|c|}
\hline Pathogen species detected & $\begin{array}{l}\text { Positive cattle } \\
(\%)\end{array}$ \\
\hline \multicolumn{2}{|l|}{ One pathogen } \\
\hline B. bovis & $8(5.2)$ \\
\hline B. bigemina & $22(14.3)$ \\
\hline T. parva & $3(1.9)$ \\
\hline T. velifera & $2(1.3)$ \\
\hline A. marginale & $12(7.8)$ \\
\hline \multicolumn{2}{|l|}{ Two pathogens } \\
\hline B.bigemina + T. parva & $3(1.9)$ \\
\hline B.bigemina + A. marginale & $11(7.1)$ \\
\hline A. marginale + T. parva & $1(0.6)$ \\
\hline A. marginale + Theileria sp. (buffalo) & $1(0.6)$ \\
\hline A. marginale $+T$. taurotragi & $1(0.6)$ \\
\hline B.bovis + B. bigemina & $2(1.3)$ \\
\hline B.bovis + A. marginale & $1(0.6)$ \\
\hline T. parva + T.velifera & $5(3.2)$ \\
\hline T. parva + T.mutans & $1(0.6)$ \\
\hline \multicolumn{2}{|l|}{ Three pathogens } \\
\hline B.bovis + B. bigemina + A. marginale & $2(1.3)$ \\
\hline B. bovis + T. parva $+T$. ovis & $1(0.6)$ \\
\hline B.bigemina $+T$. parva $+T$. mutans & $3(1.9)$ \\
\hline B. bigemina $+T$. parva $+T$. velifera & $4(2.6)$ \\
\hline B. bigemina $+T$. parva $+T$. ovis & $1(0.6)$ \\
\hline B. bigemina $+T$. taurotragi $+T$. mutans & $1(0.6)$ \\
\hline B. bigemina $+T$. taurotragi $+T$. parva & $4(2.6)$ \\
\hline B.bigemina + A. marginale $+T$. taurotragi & $1(0.6)$ \\
\hline B.bigemina + A. marginale $+T$. parva & $1(0.6)$ \\
\hline A. marginale $+T$. parva $+T$. taurotragi & $2(1.3)$ \\
\hline A. marginale $+T$. parva $+T$. velifera & $4(2.6)$ \\
\hline A. marginale $+T$. parva $+T$. orientalis & $2(1.3)$ \\
\hline A. marginale + T. parva + T. mutans & $1(0.6)$ \\
\hline \multicolumn{2}{|l|}{ Four pathogens } \\
\hline B. bigemina + A. marginale $+T$. parva + T. taurotragi & $1(0.6)$ \\
\hline B. bigemina + A. marginale $+T$. parva $+T$. ovis & $1(0.6)$ \\
\hline B. bigemina + A. marginale $+T$. parva + T. mutans & $3(1.9)$ \\
\hline \multicolumn{2}{|l|}{ Five pathogens } \\
\hline $\begin{array}{l}\text { B.bovis }+ \text { B. bigemina }+ \text { A. marginale }+ \text { T. parva }+ \\
\text { T.orientalis }\end{array}$ & $1(0.6)$ \\
\hline $\begin{array}{l}\text { B.bovis + B. bigemina }+ \text { A. marginale }+T \text {. parva }+T \text {. } \\
\text { mutans }\end{array}$ & $2(1.3)$ \\
\hline $\begin{array}{l}\text { B.bovis }+B \text {. bigemina }+ \text { A. marginale }+T \text {. parva }+T \text {. } \\
\text { taurotragi }\end{array}$ & $1(0.6)$ \\
\hline $\begin{array}{l}\text { B.bovis }+B \text {. bigemina }++A . \text { marginale }+T \text {. parva }+T \text {. } \\
\text { velifera }\end{array}$ & $1(0.6)$ \\
\hline Total & $110(71.4)$ \\
\hline
\end{tabular}


Table 5 Tick-borne hemoparasites detected in cattle $(n=38)$ from Machakos-farm in Kenya

\begin{tabular}{ll}
\hline Pathogen species detected & Positive cattle (\%) \\
\hline One pathogen & $6(15.8)$ \\
B. bovis & $1(2.6)$ \\
T. velifera & $3(7.9)$ \\
A. marginale & \\
Two pathogens & $1(2.6)$ \\
B.bigemina + T. parva & $1(2.6)$ \\
B.bigemina + T. taurotragi & $1(2.6)$ \\
B.bovis + B. bigemina & $2(5.3)$ \\
T. parva $+T$. velifera & $1(2.6)$ \\
T. taurotragi + T.velifera & $1(2.6)$ \\
T. parva $+T$. taurotragi & \\
Three pathogens & $2(5.3)$ \\
B. bovis $+T$. parva $+T$. mutans & $2(5.3)$ \\
B. bigemina $+T$. parva $+T$. velifera & $2(5.3)$ \\
A. marginale $+T$. parva $+T$. velifera & $1(2.6)$ \\
A. marginale $+T$. parva $+T$. mutans & $1(2.6)$ \\
T. parva $+T$. taurotragi $+T$. velifera & $25(65.8)$ \\
Total &
\end{tabular}

\section{Blast analysis and sequence alignment}

To establish the genotypes of these tick-borne pathogens, sequences of SBP-4, RAP-1a, Msp5, p104 and MPSP genes found in B. bovis, B. bigemina, A. marginale, $T$. parva and $T$. orientalis, respectively were genetically characterized. The identity values among the nucleotides sequences of $B$. bovis SBP-4 determined in this study [KP347555, KP347556 and KP347557] ranged from 99.6 to $99.8 \%$. Blastn analysis revealed that two Kenyan B. bovis isolates [KP347555 and KP347557] shared $99 \%$ nucleotide sequence identity with an isolate from Egypt [KF192807], while the other Kenyan isolate [KP347556] shared $100 \%$ sequence identity with the isolates from South Africa [KF626630 and AB569303] and Ghana [AB569301]. The multi-sequence alignment of $B$. bovis SBP-4 amino acid residues revealed that the Kenyan isolates contained additional amino acid residues and a specific pattern of substitutions unique to isolates obtained from African cattle (Table 6). For B. bigemina, the identities among Kenyan RAP-1a sequences ranged from 99.6 to $99.9 \%$. A further blastn analysis of RAP-1a sequences revealed that the $B$. bigemina Kenyan isolates shared between $99 \%$ and $100 \%$ nucleotide identities with the sequence of an Egyptian isolate [KF192811].

Table 6 Alignments of amino acid substitutions observed in the SBP-4 gene of Kenya B. bovis isolates in comparison with sequences from other geographic areas

\begin{tabular}{|c|c|c|c|c|c|c|c|c|c|c|c|c|c|c|c|c|c|c|c|c|c|c|c|c|}
\hline \multirow[t]{2}{*}{ Isolate } & & & & 1 & 1 & 1 & 1 & 1 & 1 & 1 & 1 & 1 & 1 & 1 & 1 & 1 & 1 & 1 & 2 & 2 & 2 & 2 & 2 & 2 \\
\hline & & & 1 & 1 & 2 & 3 & 3 & 3 & 3 & 3 & 3 & 3 & 4 & 4 & 5 & 7 & 7 & 9 & 0 & 2 & 2 & 5 & 6 & 7 \\
\hline GenBank ID & Country & Source & 0 & 8 & 9 & 2 & 3 & 4 & 5 & 6 & 7 & 8 & 2 & 8 & 9 & 2 & 3 & 2 & 4 & 1 & 8 & 4 & 3 & 0 \\
\hline XM_001610418 & USA & Cattle & $E$ & $\mathrm{~T}$ & G & - & - & - & - & - & - & $A$ & $\mathrm{D}$ & 1 & $\mathrm{D}$ & V & $\mathrm{S}$ & $\mathrm{D}$ & $\mathrm{F}$ & $L$ & $A$ & $\mathrm{~F}$ & $\mathrm{~T}$ & A \\
\hline AB569300 & Brazil & Cattle & $*$ & $*$ & * & - & - & - & - & - & - & * & * & $*$ & $*$ & $*$ & * & * & * & $*$ & * & * & $*$ & * \\
\hline AB569302 & Mongolia & Cattle & K & $*$ & $*$ & - & - & - & - & - & - & * & * & $*$ & $*$ & $*$ & * & * & $*$ & $*$ & * & $*$ & $*$ & * \\
\hline AB571871 & Thailand & Cattle & K & $*$ & * & - & - & - & - & - & - & * & $\mathrm{N}$ & * & $*$ & $*$ & $\mathrm{~T}$ & * & $L$ & $*$ & * & $*$ & $*$ & * \\
\hline AB586125 & Thailand & Water buffalo & $*$ & $*$ & * & - & - & - & - & - & - & $*$ & * & $*$ & $*$ & $*$ & * & * & $*$ & $F$ & * & $*$ & $*$ & * \\
\hline AB617641 & Syria & Cattle & $*$ & * & * & - & - & - & - & - & - & * & * & $*$ & $E$ & $*$ & $*$ & * & $*$ & $*$ & * & * & $*$ & * \\
\hline KF192805 & Egypt & Water buffalo & $*$ & * & * & - & - & - & - & - & - & * & * & $*$ & $*$ & $*$ & $*$ & * & $*$ & $*$ & * & $*$ & $*$ & * \\
\hline KF626638 & South Africa & Cattle & $*$ & $A$ & * & - & - & - & - & - & - & * & * & V & $*$ & $*$ & * & $\mathrm{D}$ & * & $*$ & $S$ & $*$ & * & * \\
\hline KF626636 & South Africa & Cattle & $*$ & $*$ & * & - & - & - & $A$ & $E$ & $\mathrm{G}$ & $\mathrm{T}$ & * & $*$ & $*$ & $*$ & $*$ & $\mathrm{~N}$ & $*$ & $*$ & $\mathrm{~S}$ & $*$ & $A$ & G \\
\hline KF626634 & South Africa & Cattle & * & $*$ & $*$ & - & - & - & A & $E$ & $G$ & $*$ & * & $*$ & $*$ & $*$ & $*$ & $\mathrm{~N}$ & $*$ & $*$ & $\mathrm{~S}$ & $*$ & A & G \\
\hline KF626635 & South Africa & Cattle & * & $*$ & * & - & - & - & A & $E$ & G & $*$ & * & $*$ & $*$ & I & * & $\mathrm{N}$ & * & $*$ & $\mathrm{~S}$ & $*$ & $A$ & G \\
\hline AB569301 & Ghana & Cattle & $*$ & $*$ & * & A & $E$ & G & A & $E$ & $\mathrm{G}$ & * & * & $*$ & $*$ & I & $*$ & $\mathrm{~N}$ & $*$ & $*$ & $S$ & $*$ & $A$ & G \\
\hline AB569303 & South Africa & Cattle & $*$ & $*$ & $*$ & A & $E$ & G & $A$ & $E$ & G & * & * & $*$ & $*$ & I & * & $\mathrm{N}$ & * & $*$ & $\mathrm{~S}$ & * & $A$ & G \\
\hline KF192806 & Egypt & Cattle & $*$ & $*$ & $\mathrm{R}$ & $A$ & $E$ & G & $A$ & $E$ & G & * & * & $*$ & $*$ & I & $*$ & $N$ & $*$ & $*$ & $\mathrm{~S}$ & $*$ & $A$ & G \\
\hline KF192807 & Egypt & Cattle & * & $*$ & * & A & $E$ & G & A & $E$ & G & * & * & * & $*$ & I & * & $\mathrm{N}$ & * & $*$ & $\mathrm{~S}$ & S & $A$ & G \\
\hline KP347555 & Kenya & Cattle & * & * & * & A & $E$ & G & $A$ & $E$ & G & * & * & $*$ & $*$ & I & $*$ & $\mathrm{~N}$ & $*$ & $*$ & $S$ & $*$ & $A$ & G \\
\hline KP347556 & Kenya & Cattle & $*$ & $*$ & * & A & $E$ & G & A & $E$ & $G$ & * & * & * & $*$ & I & * & $\mathrm{N}$ & $*$ & $*$ & $\mathrm{~S}$ & $*$ & $A$ & G \\
\hline KP347557 & Kenya & Cattle & $*$ & $*$ & $*$ & $A$ & $E$ & G & $A$ & $E$ & $\mathrm{G}$ & $*$ & * & $*$ & $*$ & I & $*$ & $\mathrm{~N}$ & $*$ & $*$ & $\mathrm{~S}$ & $*$ & $A$ & G \\
\hline
\end{tabular}

Identical residues are indicated by stars $\left(^{*}\right)$. Numbers above the alignments represent the amino acid position taking Babesia bovis T2Bo (XM_001610418) as reference sequence. The sequences determined in this study are shown in bold-font 
The A. marginale Msp5 sequences identified in this study [KP347553 and KP347554] shared $99.8 \%$ identity with each other and were homologous to the sequences of isolates from Australia [CP006847], the Philippines [AB704328] and China [EF546443].

The identities among the T. parva p104 sequences ranged from 97.8 to $98.9 \%$. The Kenyan T. parva isolates detected were genetically different from $T$. parva isolates previously reported in Kenya. One of the T. parva isolates [KP347564] shared $99 \%$ nucleotide identity with a previously published sequence from Kenya [AY034071]. However, the other two isolates [KP347565 and KP347566] shared $99 \%$ nucleotide sequence identity with isolates from Zambia [AB739676 and AB739678], Zimbabwe [AY034070] and Kenya [AY034069]. Only one T. parva isolate [KP347565] was prevalent in Machakos farm while all the three isolates found in this study were detected in samples from Ngong farm. The identities among the four T. orientalis MPSP sequences of this study ranged from 86.5 to $99.5 \%$. The nucleotide sequences of three T. orientalis isolates [KP347560, KP347562 and KP347563] were conserved and shared $99 \%$ sequence identity with T. buffeli [AB016278], a hemoparasite, previously isolated in Kenya. The other isolate [KP347561] shared $99 \%$ sequence identity to the isolates from China [KJ020560 and AB571974], Thailand [AB562563] and Japan [AB218444].

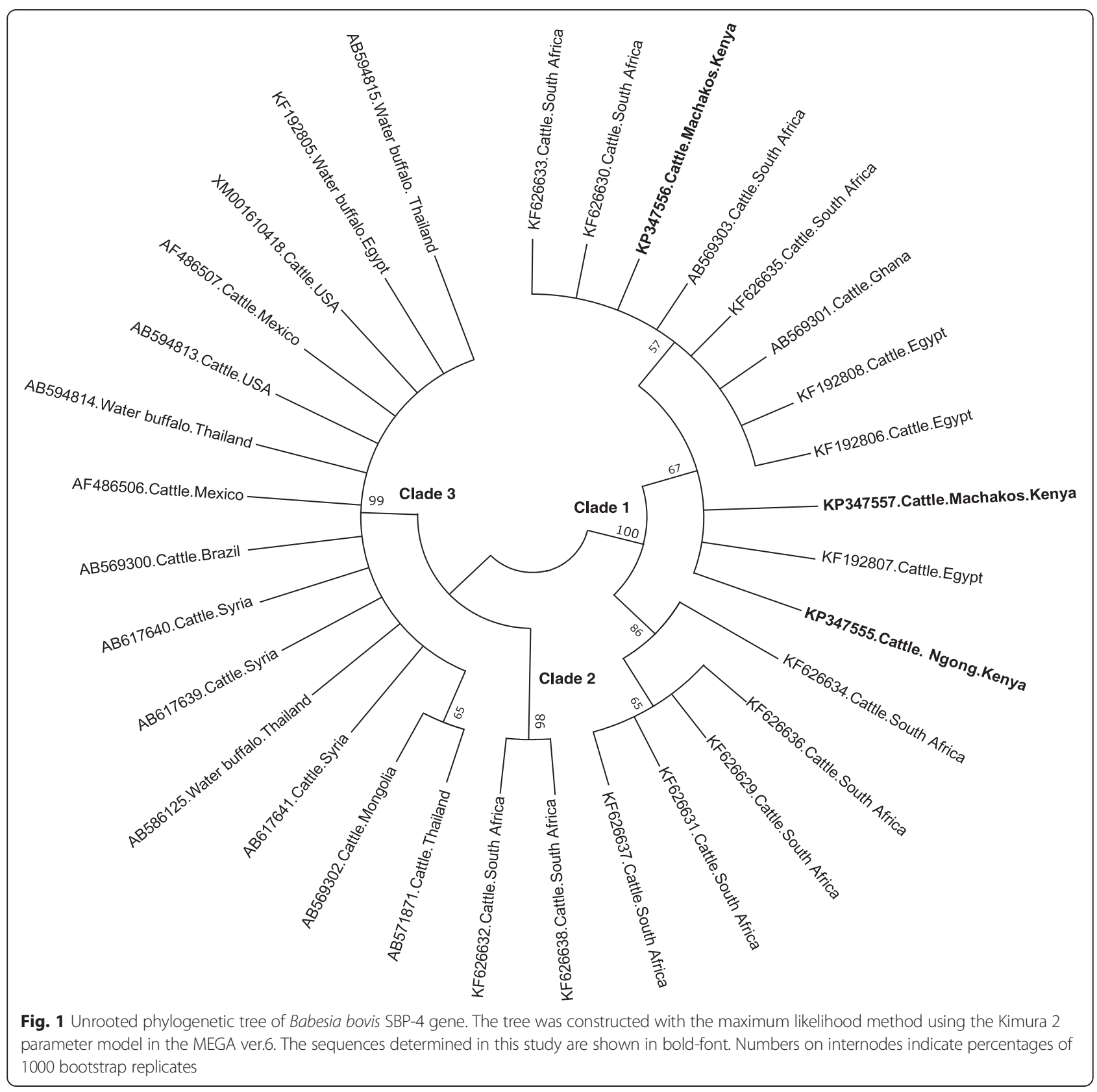




\section{Phylogenetic analysis}

Phylogenetic analyses were done to determine whether the tick-borne pathogens are genetically diverse within different geographical regions of the world. Analysis based on SBP-4 gene grouped the Kenyan B. bovis isolates in the same clade (Clade 1) as Egyptian, Ghanaian and South African isolates (Fig. 1). The other B. bovis isolates from Thailand, Syria, Mexico, Brazil, Mongolia and United States of America (USA) were grouped in a separate clade. The Kenyan B. bigemina isolate belonged to the same clade as the isolates from Egypt, Thailand, Syria and Mexico (Fig. 2). A further phylogeny using the Msp5 gene grouped the Kenyan A. marginale isolates in the same clade as the isolates from China, Australia, Brazil and The Philippines (Fig. 3). However, isolates from USA and Cuba were grouped in a different clade. For T. parva, the [KP347565] and [KP347566] isolates were closely related to the cattle-derived genotypes while the other isolate [KP347564] was related to the buffaloderived T. parva genotypes (Fig. 4). The polymorphism of T. parva p104 nucleotide sequences is shown in an additional file [see Additional file 3]. The phylogenetic analysis based on MPSP gene of T. orientalis/sergenti/ buffeli grouped three of the isolates of this study [KP347560, KP347562 and KP347563] in the same clade and these isolates were classified as MPSP type 3. The divergent isolate [KP347561] belonged to a separate clade and was identified as MPSP type 5 (Fig. 5).

\section{Discussion}

This study was done to determine the genetic diversities as well as molecular epidemiology of $B$. bovis, B. bigemina, Theileria spp. and $A$. marginale isolates of cattle raised in Machakos and Ngong districts of Kenya. Such information is critical for controlling and preventing infections caused by these pathogens, which leads to loss of livelihoods of many livestock owners [30]. The causative agents of babesiosis, theileriosis, and anaplasmosis were prevalent in the two farms surveyed. These findings are consistent with previous reports ranking tick-borne pathogens as important causes of diseases in Kenyan cattle [6-8, 31, 32]. Though Theileria spp. has always been reported to be the most prevalent hemoparasite in Kenya [8, 11, 12], this was not the case in Ngong farm as Babesia species were the most prevalent pathogens. However, Theileria species were more prevalent in Machakos farm consistent with the previous studies in Kenyan cattle [8, 11, 12]. A. marginale was the least prevalent in both farms suggesting that it may not be one of the most prevalent tick-borne diseases in these regions.

The prevalence of B. bovis was higher than that of $B$. bigemina in Machakos and vice-versa in Ngong farm indicating that the epidemiology of babesiosis in the two farms may be different. The prevalence of B. bigemina reflects the distribution of its vectors, Rhipicephalus evertsi and $R$. decoloratus [1] which are both present in Machakos and Ngong districts [8,33]. B. bigemina is the

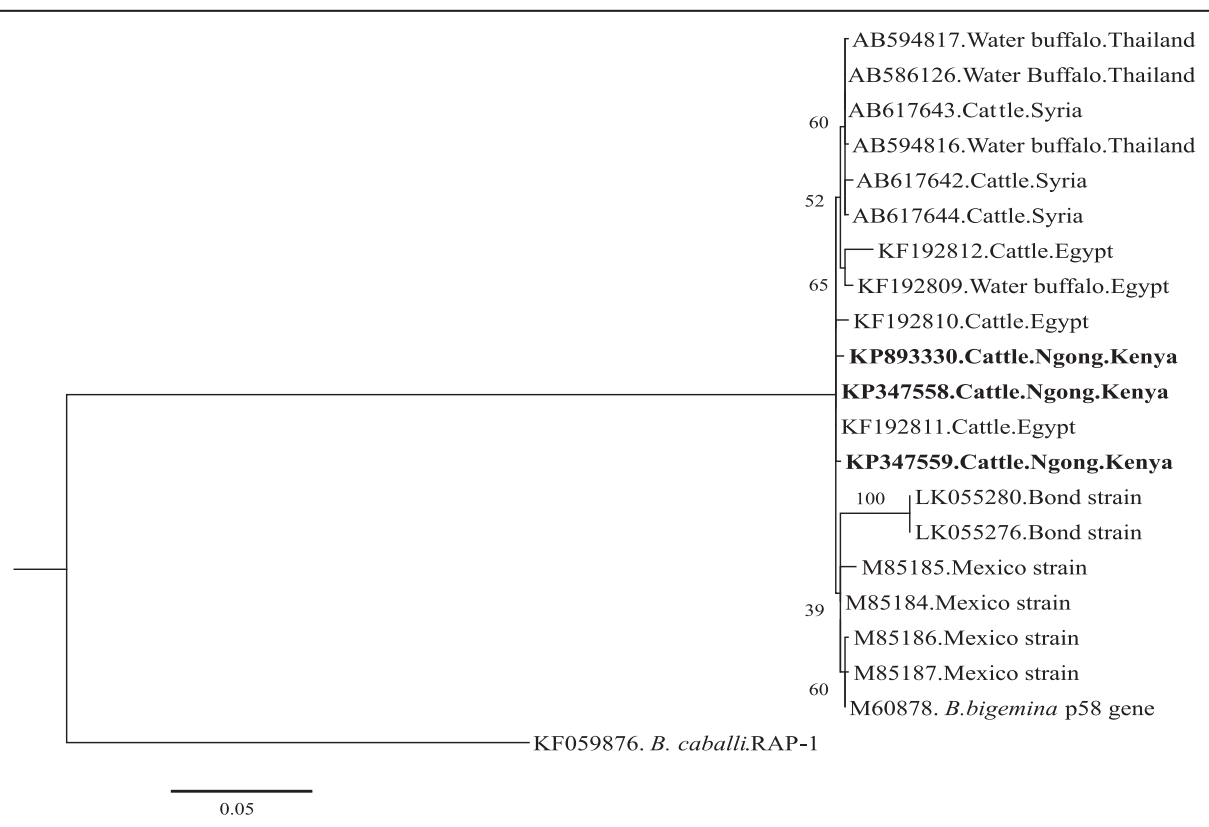

Fig. 2 Phylogenetic analyses of B. bigemina RAP-1a gene sequences obtained from Kenyan cattle. B. caballi Rhoptry-associated protein-1(RAP1) gene was used as outgroup. The tree was constructed with the maximum likelihood method using the Kimura 2 parameter model in the MEGA ver.6. The sequences determined in this study are shown in bold-font. Numbers on the branches show percentages of 1000 bootstrap replications. The scale bar indicates estimated number of substitutions per site 


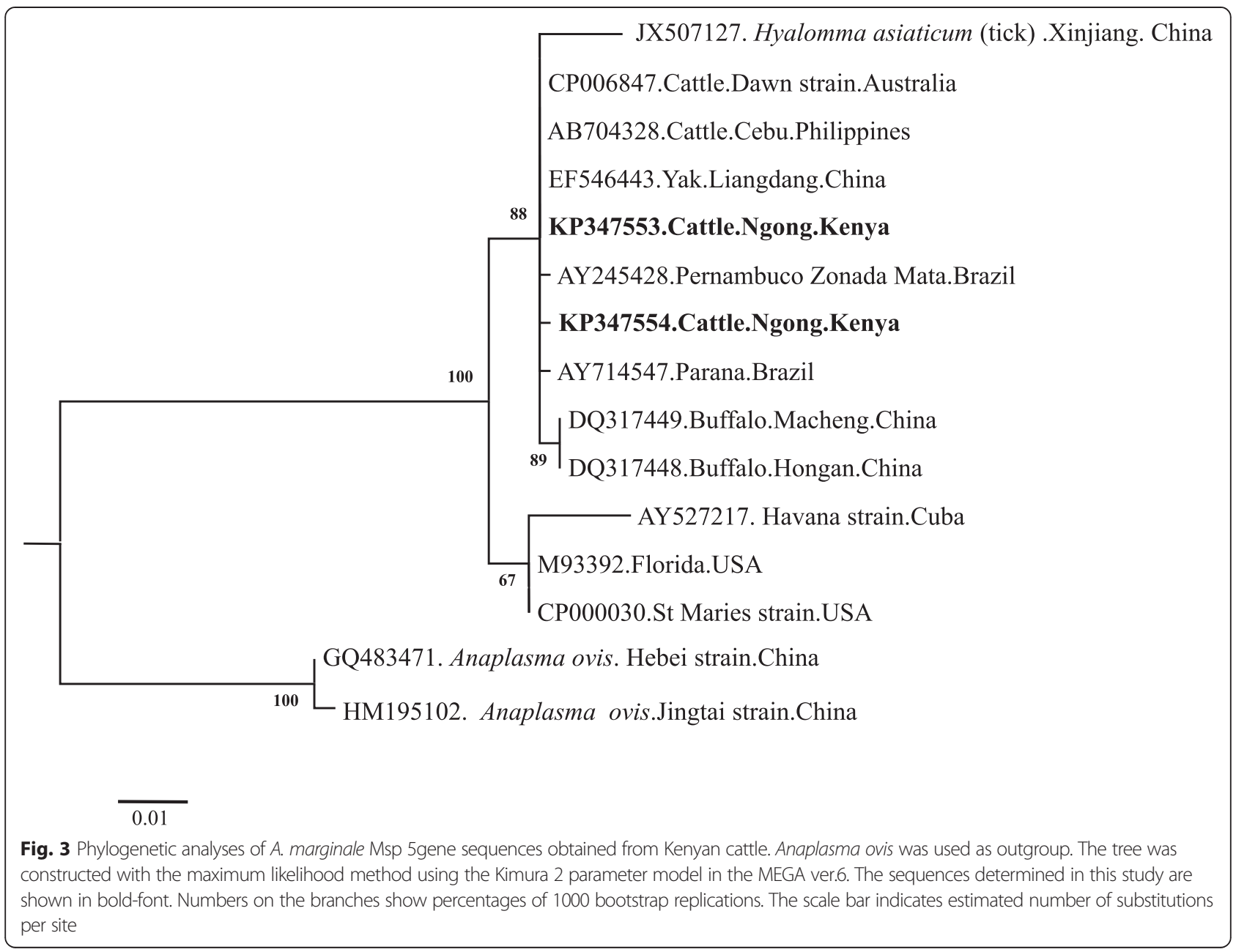

main cause of bovine babesiosis in Kenya [8, 34] and its predominance in Ngong farm is not surprising. The low prevalence of B. bigemina in Machakos farm could be explained by lower exposure to tick vectors. The detection of $B$. bovis was unexpected since none of its vectors namely, $R$. microplus, $R$. geigyi and $R$. annulatus [1] have been reported in the two districts. Our results, therefore indicate that $B$. bovis has been overlooked or is becoming endemic in Machakos and Ngong districts. The competition between $R$. microplus and $R$. decoloratus may explain why $B$. bigemina is more widespread than $B$. bovis in Africa [1]. Hence, the higher prevalence of $B$. bovis in Machakos farm suggests changes in tick distribution. Uncontrolled animal movement that is common in Kenya [34] or changes in ecological pattern may have contributed to the thriving of $B$. bovis tick-vectors.

This study revealed higher prevalences of $B$. bovis and $B$. bigemina than those previously observed in Western Kenya [16, 17]. This may not be surprising as the studies were done in different ecological areas. B. bovis, B. bigemina isolated in the two farms were genetically conserved and closely related to isolates from other African countries.
B. bovis SBP-4 sequences from Kenya were consistent with the findings of [35] which indicated the existence of a "fingerprint" discriminating $B$. bovis isolates of African cattle from others. However, B. bovis SBP-4 phenogram showed the existence of an "intermediate" clade (Clade 2, Fig. 1) hosting sequences from South Africa which despite being isolated from cattle were not bearing the discriminatory "fingerprint". Hence, further studies on B. bovis SBP-4 gene in other African countries are needed for clarification of the scope, the origin and impact on the parasite of this "fingerprint".

The detection of $A$. marginale DNA in both farms is consistent with previous studies which reported antibodies to A. marginale in Kenyan cattle [8, 12-14]. The sequence identity of the two $A$. marginale genotypes detected in this study suggests that the parasite isolates circulating in Kenya may be genetically conserved. However, further studies are required to unravel the genetic diversity of the parasite isolates.

Although this study detected Theileria species in both farms, the samples analyzed here were not large enough and elaborate studies will be needed to determine the 


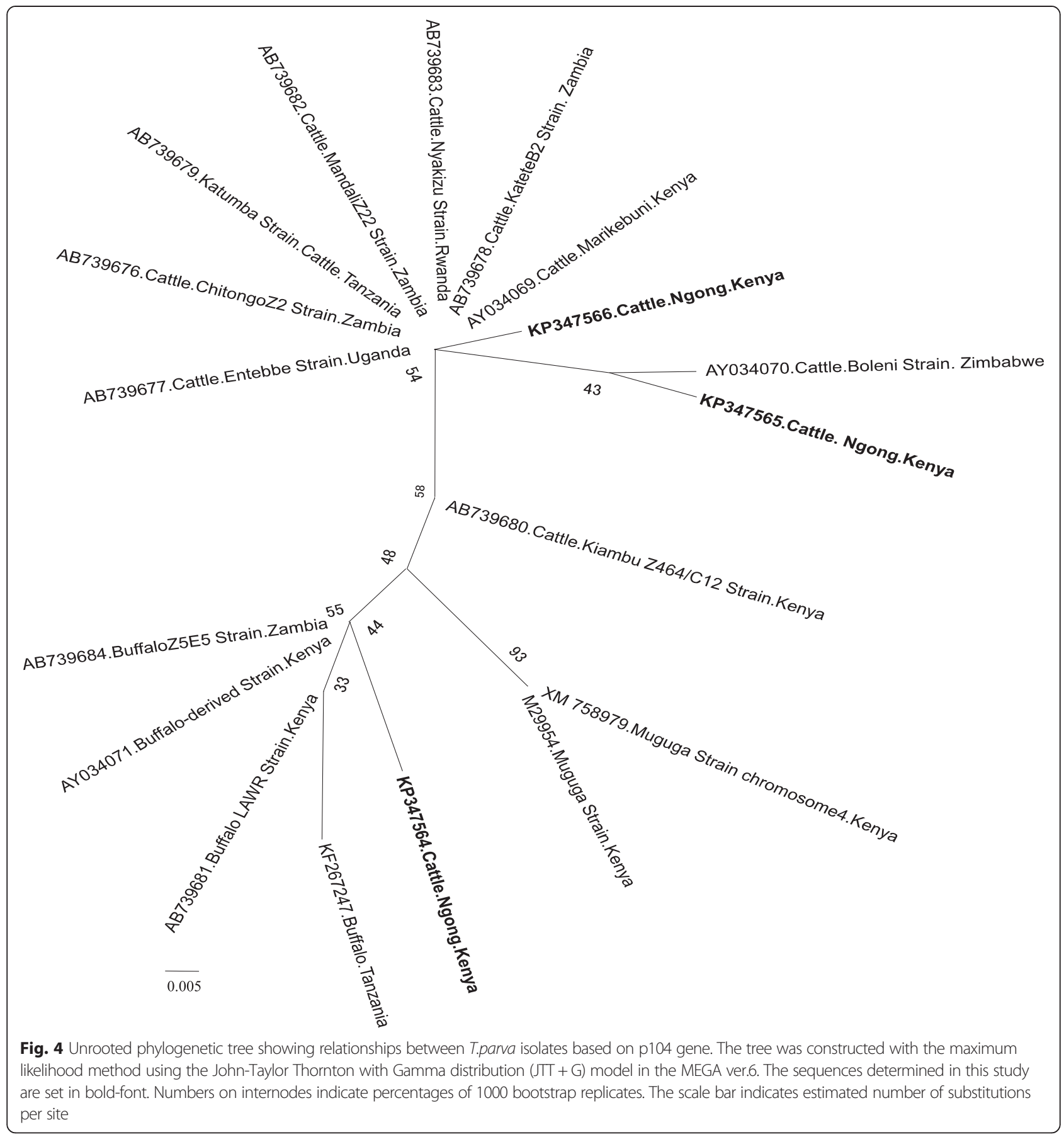

full extent of the infections in Kenya. Many Theileria species including $T$. parva, $T$. taurotragi, $T$. mutans and $T$. velifera were detected in both farms. However, T.orientalis/sergenti/buffeli, T. ovis and Theileria sp. (buffalo) were detected only in Ngong farm. Cattle are the natural host of $T$. parva, T. taurotragi, T. mutans and T. velifera. R.appendiculatus, which transmits T. parva and T. taurotragi as well as Amblyomma variegatum, the vector for $T$. mutans and $T$. velifera are known to exist in the districts surveyed $[8,33]$. Therefore, the presence of these tick vectors may explain the occurrences of the hemoparasites in the farms. T. ovis is known to infect small ruminants [36] while T. buffeli and Theileria sp. (buffalo) infect African Cape buffalo (Syncerus caffer) [37]. The detection of buffalo-Theileria isolates in Ngong farm-cattle may be attributed to their transmission by ticks and interaction of these cattle with nomadic Maasai cattle. These Maasai cattle usually graze together with wildlife including buffaloes. Likewise, Maasai cattle are generally kept with flocks of small ruminants and therefore can be a source of $T$. 


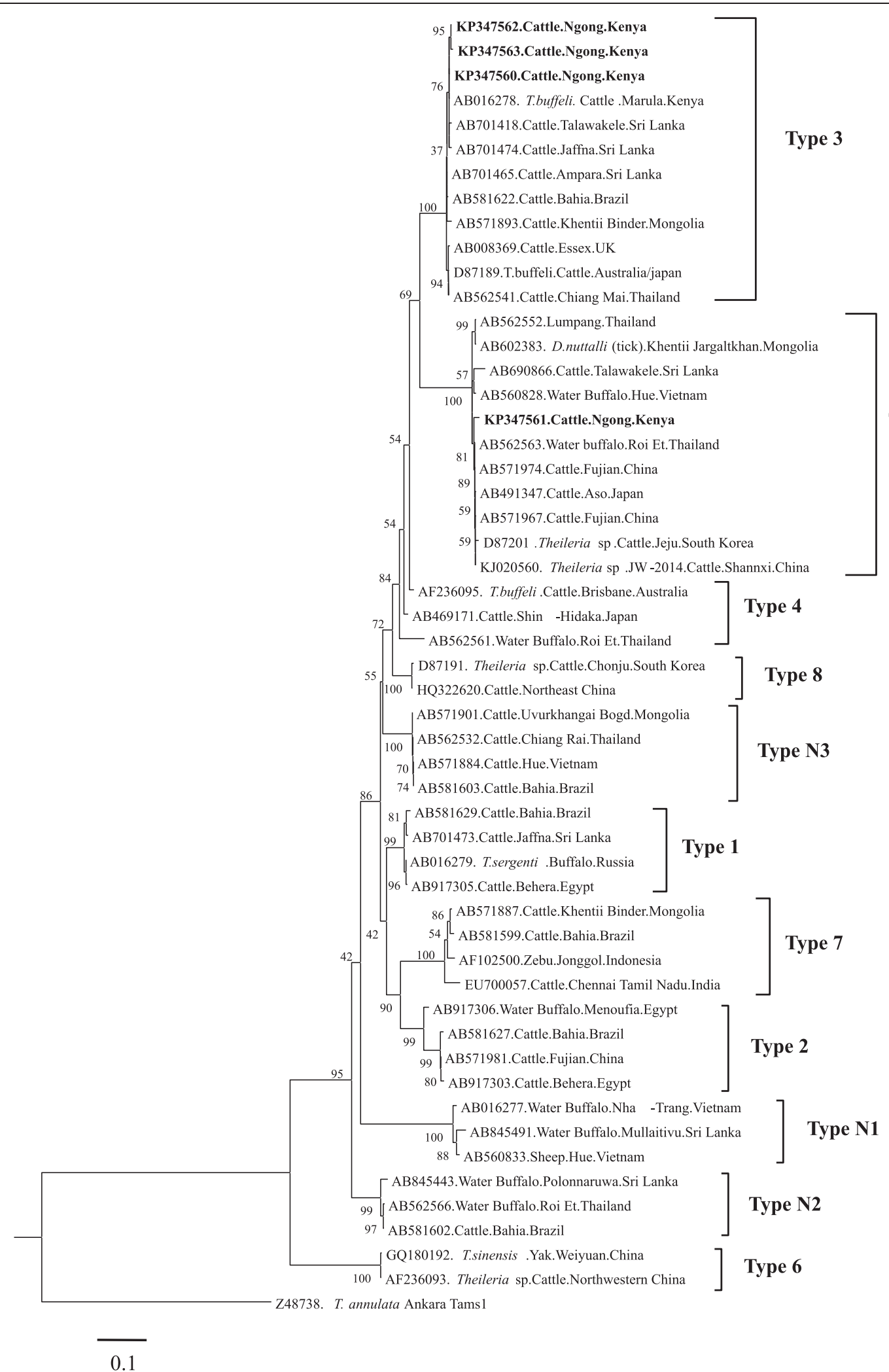

Fig. 5 (See legend on next page.) 
(See figure on previous page.)

Fig. 5 Phylogenetic analyses of T. orientalis MPSP gene sequences obtained from Kenyan cattle. The tree was constructed with the maximum

likelihood method using the Tamura 3 parameter with Gamma distribution $(T 92+\mathrm{G})$ model in the MEGA ver. 6 . T. annulata (Ankara strain) merozoite

surface antigen 1 gene (Tams1) was used as outgroup. The sequences determined in this study are shown in bold-font. Numbers on the branches

show percentages of 1000 bootstrap replications. The scale bar indicates estimated number of substitutions per site

ovis-infected ticks for Ngong farm-cattle. Such accidental Theileria infections in cattle have previously been reported in wildlife-domestic animals interface and in areas where there is high animal movement in Kenya [15-17]. Before this study, only one MPSP allele of T. sergenti/ buffeli/orientalis had been isolated in Kenya [38, 39]. The polymorphism of the T. orientalis MPSP type 3 isolates identified and the description for the first time of $T$. orientalis MPSP type 5 indicate that at least two strains of this benign Theileria parasite are present in Kenya. None of the T. orientalis MPSP alleles identified in Kenya have ever been associated to disease outbreaks. However, in Ethiopia [40], Burundi [41], India [42], Australia [43-45] and New Zealand [46], some T. orientalis strains have caused disease outbreaks. Hence, T. orientalis complex should not be ruled out as a probable cause of disease, particularly for crossbred and exotic breeds dairy cattle reared in Kenya.

T. parva was the most frequent Theileria in the two farms. Although they were positive for both Theileria $18 \mathrm{~S}$ rRNA and T. parva p104 nPCRs, sequencing of the Theileria 18S rRNA amplicons of 35 samples from Ngong farm and 11 samples from Machakos farm, did not show a sequence specific to $T$. parva. This is probably due to low levels of $T$. parva-parasitemia and to several Theileria species co-occurring in the same animal. In the current study, genus specific primers were used to amplify Theileria $18 \mathrm{~S}$ rRNA and obtained products therefore contained amplicons from several species. Only amplicons derived from species with abundant DNA were reflected in the sequencing chromatogram. Hence, T. parva $18 \mathrm{~S}$ rRNA was not identified in some samples because it was outnumbered by the $18 \mathrm{~S}$ rRNA gene of other Theilera species. East Coast fever (ECF) caused by T. parva is the most important tick-borne disease in Kenya, and "immunization" against it is common $[6,47,48]$. The carrier state is particularly important for this parasite as it contributes to and may be necessary for maintenance of immunity against overt disease $[18,36]$. Most of T. parva positive animals in this study seemed to be carriers and previous studies [49-51] suggested that such status could have been induced by previous "immunization" as well as natural infection. T. parva prevalences obtained were lower than the $67 \%$ observed in Marula, Rift Valley [15], similar to the values recorded by [18] but higher than the RLB data from Western Kenya $[16,17]$. The detection of T. parva isolate in Machakos farm and not the buffalo-derived genotypes suggested that these cattle are only exposed to the cattle-derived $T$. parva. The identification of buffalo-derived genotypes in Ngong farm corroborates previous reports of the occurrence of buffalo-derived $T$. parva in cattle in Kenya $[33,34]$.

All the cattle in this study appeared healthy, although pathogenic hemoparasites (B. bovis, B. bigemina, $A$. marginale and $T$. parva) were detected in their blood. This absence of clinical disease in infected cattle may be attributed to a state of enzootic stability as described in previous reports $[1,3,4]$. The high rate of multiple infections in both farms, sometimes involving hemoparasites belonging to different genus may be explained by the presence of a range of tick-vectors that exist in the same ecosystem. Benign T. taurotragi, and T. mutans detected in this study have been previously associated with morbidity and mortality in calves in Kenya [52, 53]. Perhaps further studies should explore the importance of these hemoparasites in Kenya with regard to Theileria infections in calves. SBP-4, RAP-1a, Msp5 and MPSP genes, and the corresponding PCR assays were exploited for the first time in Kenya. Our findings confirm the value of these assays [21, 22, 24, 35, 45] and suggest that they can be used to improve hemoparasites detection in Kenya.

\section{Conclusions}

This study has confirmed the occurrences of a range of genetically diverse tick-borne hemoparasites in farms located in two districts of Kenya. The detection, prevention and control of these hemoparasites in cattle should consider their genotypes, the co-infective nature of these pathogens and the role of wildlife in the transmissions of the tick-borne parasites. Therefore, this study will provide a basis for further research on tick-borne hemoparasitic diseases and their molecular epidemiology in Kenya and other regions of the world.

\section{Additional files}

Additional file 1: Table S1. Results of hemoparasites DNAs detection by $\mathrm{nPCR}$. This table presents individual results for each parasite per study farm. (DOCX $21 \mathrm{~kb}$ )

Additional file 2: Table S2. Theileria species detected in cattle from Ngong-farm and Machakos-farm in Kenya. This table summarizes the results of the identification of Theileria infections based Theileria spp. 18S RNA amplicons, T. parva p104 nPCR and T. orientalis MPSP PCR. (DOCX 25 kb)

Additional file 3: Table S3. Nucleotide alignment of partial sequences of T. parva p104 gene. This table presents a multi-sequence alignment of T. parva p104 sequences which compares the sequences obtained in this study to those previously published. (XLSX 28 kb) 


\section{Abbreviations}

BLAST: Basic local alignment tool; DNA: Deoxyribonucleic acid; EDTA: Ethylenediaminetetraacetic acid; ECF: East coast fever; Msp5: Major surface protein 5; MPSP: Major piroplasm surface protein; NCBI: National center for biotechnology information; nPCR: Nested PCR; PCR: Polymerase chain reaction; RAP-1a: Rhoptry-associated protein 1a; SBP-4: Spherical body protein 4; $18 \mathrm{~S}$ rRNA: component of the small subunit of the ribosomal ribonucleic acid; Tams1: T. annulata merozoite surface antigen 1.

\section{Competing interests}

The authors declare that they have no competing interest.

\section{Authors' contributions}

PFAM, GOA and XX: Developed the conception and design of the study, oversaw the collection of cattle blood samples. PFAM, KK, CJ, MZ, GW, ML, Al and PV: Performed the experiments. PFAM, TM and SC: Carried out the sequences analyses. PFAM, GOA, MAT and XX: Carried out data analysis, intellectual interpretation and wrote the manuscript. APY and HI: provided critical advice and materials for A. marginale detection. RSU and HS: contributed to data analysis. All authors read and approved the final manuscript.

\section{Acknowledgments}

The authors would like to thank Dr. Sugimoto Chihiro from the Research Center for Zoonosis Control, Hokkaido University, Japan for supplying the DNAs of T. parva (Muguga G6,ILRI) and T.annulata (Ankara C9,Edinburgh University), and Dr. Jose Maria Angeles from the National Research Center for Protozoan Diseases, Obihiro University of Agriculture and Veterinary Medicine, Japan for his advice during the revision of this manuscript. We also acknowledge the Director of Veterinary Sciences, Nairobi, Kenya for facilitating sample collection and Mr. Justo Challo Kasiva for assisting with the DNA extractions. This study was supported by a Grant-in-Aid for Scientific Research from Ministry of Education, Culture, Sports, Science and Technology (MEXT), Japan.

\section{Author details}

${ }^{1}$ National Research Center for Protozoan Diseases, Obihiro University of Agriculture and Veterinary Medicine, Obihiro, Hokkaido 080-8555, Japan. ${ }^{2}$ Department of Public Health, Pharmacology and Toxicology, Faculty of Veterinary Medicine, University of Nairobi, Kangemi, Nairobi 00625, Kenya. ${ }^{3}$ United Graduate School of Veterinary Sciences, Gifu University, Gifu, Gifu 501-1193, Japan. ${ }^{4}$ Department of Veterinary Clinical Sciences, Obihiro University of Agriculture and Veterinary Medicine, Obihiro, Hokkaido 080-8555, Japan.

\section{Received: 13 May 2015 Accepted: 22 September 2015} Published online: 30 September 2015

\section{References}

1. Bock R, Jackson L, de Vos A, Jorgensen W. Babesiosis of cattle. Parasitology. 2004;129(Suppl):S247-69.

2. Uilenberg G. Babesia-A historical overview. Vet Parasitol. 2006;138:3-10

3. Kalume MK, Losson B, Saegerman C. Epidémiologie et contrôle de la theilériose bovineàTheileria parva en Afrique: une revue de la littérature. Ann Méd Vét. 2011;155:88-104.

4. Kocan KM, de la Fuente J, Blouin EF, Coetzee JF, Ewing SA. The natural history of Anaplasma marginale. Vet Parasitol. 2010;167:95-107.

5. Jongejan F, Uilenberg G. The global importance of ticks. Parasitology. 2004;129:3-14

6. Kanyari PW, Kagira J. The role of parasitic diseases as causes of mortality in cattle in a high potential area of central Kenya: a quantitative analysis. Onderstepoort J Vet Res. 2000;67:157-61.

7. Mulei CM, Rege JEO. An examination of the incidences of East Coast fever (ECF), anaplasmosis and babesiosis in the bovine in Kabete area of Kiambu District of Kenya. Bull Anim Health Prod Afr. 1989;37:213-6.

8. Wesonga FD, Kitala PM, Gathuma JM, Njenga MJ, Ngumi PN. An assessment of tick-borne diseases constraints to livestock production in a smallholder livestock production system in Machakos District, Kenya 2010. LRRD 2010, 22. http://www.Irrd.org//rrd22/6/weso22111.htm

9. Karanja SM. Epidemiology and importance of trypanosomosis, helminthosis and tick-borne diseases on the performance of cattle in Busia district, Kenya. Berlin: FreieUniversität; 2005.
10. Latif AA, Rowlands GJ, Punyua DK, Hassan SM, Capstick PB. An epidemiological study of tick-borne diseases and their effects on productivity of zebu cattle under traditional management on Rusinga Island, western Kenya. Prev Vet Med. 1995;22:169-81.

11. Muraguri GR, McLeod A, McDermott JJ, Taylor N. The incidence of calf morbidity and mortality due to vector-borne infections in smallholder dairy farms in Kwale District, Kenya. Vet Parasitol. 2005;130:305-15.

12. Okuthe OS, Buyu GE. Prevalence and incidence of tick-borne diseases in smallholder farming systems in the western-Kenya highlands. Vet Parasitol. 2006;141:307-12.

13. Gachohi JM, Ngumi PN, Kitala PM, Skilton RA. Estimating seroprevalence and variation to four tick-borne infections and determination of associated risk factors in cattle under traditional mixed farming system in Mbeere District, Kenya. Prev Vet Med. 2010;95:208-23.

14. Kiara $H$, Jennings $A$, Bronsvoort BM, Handel IG, Mwangi ST, Mbole-Kariuki M. A longitudinal assessment of the serological response to Theileria parva and other tick-borne parasites from birth to one year in a cohort of indigenous calves in western Kenya. Parasitology. 2014;141:1289-98.

15. Githaka N, Konnai S, Bishop R, Odongo D, Lekolool I, Kariuki E, et al. Identification and sequence characterization of novel Theileria genotypes from the waterbuck (Kobus defassa) in a Theileria parva-endemic area in Kenya. Vet Parasitol. 2014;202:180-93.

16. Njiiri NE, Bronsvoort BM, Collins NE, Steyn HC, Troskie M, Vorster I, et al. The epidemiology of tick-borne haemoparasites as determined by the reverse line blot hybridization assay in an intensively studied cohort of calves in western Kenya. Vet Parasitol. 2015;210:69-76.

17. Njiiri EN. The occurrence of Ehrlichia ruminantium and other haemoparasites in calves in western Kenya determined by reverse line blot hybridization assay, real-time PCR and nested PCR. Pretoria: University of Pretoria; 2012.

18. Odongo D, Kiara H, Perry B, Skilton R, Bishop R. An investigation into the carrier state of Theileria parva by the polymerase chain reaction assay. Proc 10th Int Symp Vet Epidemiol Econ. 2003:1-3.

19. Climate-data.org. http://en.climate-data.org/. Accessed 15 December 2014.

20. Cao S, Zhang S, Jia L, Xue S, Yu L, Kamyingkird K, et al. Molecular detection of Theileria species in sheep from northern China. J Vet Med Sci. 2013;75:1227-30

21. Terkawi MA, Huyen NX, Shinuo C, Inpankaew T, Maklon K, Aboulaila M, et al. Molecular and serological prevalence of Babesia bovis and Babesia bigemina in water buffaloes in the northeast region of Thailand. Vet Parasitol. 2011:178:201-7.

22. Ybañez AP, Sivakumar T, Battsetseg B, Battur B, Altangerel K, Matsumoto K, et al. Specific molecular detection and characterization of Anaplasma marginale in Mongolian Cattle. J Vet Med Sci. 2013;75:399-406.

23. Konnai S, Imamura S, Nakajima C, Witola WH, Yamada S, Simuunza M, et al. Acquisition and transmission of Theileria parvaby vector tick, Rhipicephalus appendiculatus. Acta Trop. 2006;99:34-41.

24. Ota N, Mizuno D, Kuboki N, Igarashi I, Nakamura Y, Yamashina H, et al. Epidemiological survey of Theileria orientalis infection in grazing cattle in the eastern part of Hokkaido, Japan. J Vet Med Sci. 2009:71:937-44.

25. Mixed sequence Reader. http://msr.cs.nthu.edu.tw. Accessed 10 November 2014.

26. 26.European bio-informatics Institute. EMBOSS Needlesoftware. http:// www.bioinformatics.nl/cgi-bin/emboss/needle. Accessed 18 December 2014.

27. Guidance Software. http://guidance.tau.ac.il/. Accessed 10 March 2015.

28. Tamura K, Stecher G, Peterson D, Filipski A, Kumar S. MEGA6: Molecular evolutionary genetics analysis version 6.0. Mol Biol Evol. 2013:30:2725-9.

29. VassarStats. http://vassarstats.net/. Accessed 10 October 2014

30. Minjauw B, Mcleod A. Tick-borne diseases and poverty. The impact of ticks and tick-borne diseases on the livelihood of small-scale and marginal livestock owners in India and eastern and southern Africa. UK: Research report, DFID Animal Health Programme, Centre for Tropical Veterinary Medicine, University of Edinburgh; 2003

31. Chenyambuga SW, Waiswa C, Saimo M, Ngumi P, Gwakisa PS. Knowledge and perceptions of traditional livestock keepers on tick-borne diseases and sero-prevalence of Theileria parva around Lake Victoria Basin; 2010. LRRD 2010, 22. http://www.Irrd.org//rrd22/7/chen22135.htm.

32. Mulei CM, Gitau GK, Mbuthia PG. Causes of calf mortality in Kabete area of Kenya. Onderstepoort J Vet Res. 1995;62(3):181-5.

33. Chumo RSC, Taracha E, Morzaria SP, Irvin AD, Voigt WP, Purnell RE. East Coast fever field trial at Ngong, Kenya: isolation of Theileria parva stocks and immunization. In: Irvin AD, editor. Immunization against Theileriosis in Africa. Nairobi: ILRAD; 1985. p. 79-81. 
34. Mbogo SK. Epidemiology of ticks and tick-borne diseases in Kenya: Future research needs and priorities. In: Irvin AD, McDermott JJ, Perry BD, editors. Epidemiology of ticks and tick-borne diseases in Eastern, Central and Southern Africa. Proceedings of a Workshop Held in Harare, 12-13 March 1996. Nairobi: ILRl; 1996. p. 33-8.

35. Ibrahim HM, Adjou Moumouni PF, Mohammed-Geba K, Sheir SK, Hashem IS, Cao S, et al. Molecular and serological prevalence of Babesia bigemina and Babesia bovis in cattle and water buffalos under small-scale dairy farming in Beheira and Faiyum Provinces, Egypt. Vet Parasitol. 2013;198:187-92.

36. Bishop R, Musoke A, Morzaria S, Gardner M, Nene V. Theileria: intracellular protozoan parasites of wild and domestic ruminants transmitted by ixodid ticks. Parasitology. 2004;129(129 Suppl):S271-83.

37. Oura CA, Tait A, Asiimwe B, Lubega GW, Weir W. Theileria parva genetic diversity and haemoparasite prevalence in cattle and wildlife in and around Lake Mburo National Park in Uganda. Parasitol Res. 2011;108:1365-74.

38. Kawazu S, Kamio T, Kakuda T, Terada Y, Sugimoto C, Fujisaki K. Phylogenetic relationships of the benign Theileria species in cattle and Asian buffalo based on the major piroplasm surface protein (p33/34) gene sequences. Int J Parasitol. 1999;29:613-8.

39. Ngumi PN, Lesan AC, Williamson SM, Awich JR, Morzaria SP, Dolan TT, et al. Isolation and preliminary characterisation of a previously unidentified Theileria parasite of cattle in Kenya. Res Vet Sci. 1994;57:1-9.

40. Becerra VM, Eggen AAS, De Rooij RC, Uilenberg G. Theileria orientalis in cattle in Ethiopia. Res Vet Sci. 1983;34:362-4.

41. Kiltz HH, Uilenberg G, Franssen FF, Perié NM. Theileria orientalis occurs in Central Africa. Res Vet Sci. 1986;40:197-200.

42. Aparna M, Ravindran R, Vimalkumar MB, Lakshmanan B, Rameshkumar P, Kumar KGA, et al. Molecular characterization of Theileria orientalis causing fatal infection in crossbred adult bovines of South India. Parasitol Int. 2011;60:524-9.

43. Cufos N, Jabbar A, de Carvalho LM, Gasser RB. Mutation scanning-based analysis of Theileria orientalis populations in cattle following an outbreak. Electrophoresis. 2012;33:2036-40.

44. Eamens GJ, Gonsalves JR, Jenkins C, Collins D, Bailey G. Theileria orientalis MPSP types in Australian cattle herds associated with outbreaks of clinical disease and their association with clinical pathology findings. Vet Parasitol. 2013;191:209-17.

45. Kamau J, de Vos AJ, Playford M, Salim B, Kinyanjui P, Sugimoto C. Emergence of new types of Theileria orientalis in Australian cattle and possible cause of theileriosis outbreaks. Parasit Vectors. 2011;4:22.

46. McFadden AM, Rawdon TG, Meyer J, Makin J, Morley CM, Clough RR, et al. An outbreak of haemolytic anaemia associated with infection of Theileria orientalis in naive cattle. N Z Vet J. 2011;59:79-85.

47. Gachohi J, Skilton R, Hansen F, Ngumi P, Kitala P. Epidemiology of East Coast fever (Theileria parva infection) in Kenya: past, present and the future. Parasit Vectors. 2012;5:194.

48. Gitau GK, Perry BD, McDermott JJ. The incidence, calf morbidity and mortality due to Theileria parva infections in smallholder dairy farms in Murang'a District, Kenya. Prev Vet Med. 1999;39:65-79.

49. Oura CA, Bishop R, Wampande EM, Lubega GW, Tait A. The persistence of component Theileria parva stocks in cattle immunized with the "Muguga cocktail" live vaccine against East Coast fever in Uganda. Parasitology. 2004; 129:27-42.

50. Skilton RA, Bishop RP, Katende JM, Mwaura S, Morzaria SP. The persistence of Theileria parva infection in cattle immunized using two stocks which differ in their ability to induce a carrier state: analysis using a novel blood spot PCR assay. Parasitology. 2002;124:265-76.

51. Simuunza M, Weir W, Courcier E, Tait A, Shiels B. Epidemiological analysis of tick-borne diseases in Zambia. Vet Parasitol. 2011;175:331-42.

52. Moll G, Lohding A, Young AS, Leitch BL. Epidemiology of theileriosis in calves in an endemic area of Kenya. Vet Parasitol. 1986;19:255-73.

53. Moll G, Lohding A. Epidemiology of theilerioses in the Trans-Mara Division, Kenya: husbandry and disease background and preliminary investigations on theilerioses in calves. Preventive Vet Med. 1984;2:801-31.

\section{Submit your next manuscript to BioMed Central and take full advantage of:}

- Convenient online submission

- Thorough peer review

- No space constraints or color figure charges

- Immediate publication on acceptance

- Inclusion in PubMed, CAS, Scopus and Google Scholar

- Research which is freely available for redistribution

Submit your manuscript at www.biomedcentral.com/submit 